\title{
Obama's legacy and beyond
}

Leading journalists and academics from both sides of the Atlantic review Obama's presidency and legacy and look ahead to Trump's term in the most powerful office in the world.

\section{OBAMA THE PROGRESSIVE}

\section{Elizabeth Anderson is professor of philosophy and women's studies at the University of Michigan.}

Obama has been the best US president by far in my lifetime which includes the tail end of Eisenhower's term. Our outgoing president has advanced the most consequential progressive domestic policy agenda since Lyndon B Johnson.

Allow me to list some of Obama's biggest accomplishments. He achieved the closest thing to universal healthcare the US has seen, in the face of massive political opposition - the top agenda item for progressives since Truman. His stimulus bill ensured a more rapid recovery from the great recession than that experienced by peer countries in the EU, which have pursued counterproductive austerity policies. He rescued millions of good jobs by supplying loans to the vehicle industry, preventing its collapse in the financial crisis. He oversaw a major banking reform, which reduces the chance that banks will cause future financial crises and provides consumer protections from deceptive financial practices. He strengthened women's rights to equal pay for equal work. He raised the minimum wage for employees of government contractors. He ended banks' usurious involvement in federal student loans, dramatically reducing the costs to students of borrowing for college. He made the federal tax system substantially more progressive.

Obama's Department of Justice has vigorously advanced minority voting rights and has taken major initiatives to reduce racist policing and incarceration practices. His supreme court appointees ensured that gay and lesbian couples have the right to marry. He has banned federal contractors from discriminating against LGBT employees. He suspended the deportation of undocumented immigrants who entered the US as children. His energy and environmental policies have reduced the country's greenhouse gas emissions and committed it to dramatic reductions in the future. 
I could list hundreds more progressive achievements. And unlike LBJ, Obama has nothing comparable to the catastrophic Vietnam war to mar this legacy. (Afghanistan may be a quagmire, but the scale of the problem is much smaller than in Vietnam.) Unfortunately, although I think his reputation will only grow over time, the election threatens to dismantle many of his achievements, as it hands total control of the federal government to the Republicans. Republicans in congress are likely to find this more difficult to achieve than they anticipate, however, and they will court disaster if they go too far.

The election result means the path to cementing Obama's legacy is now longer and rockier than it might have been, but I am hopeful that ultimately consolidation will be achieved.

\section{A LEGACY HIGHJACKED}

\section{Jedediah Purdy is Robinson O. Everett professor of law at Duke University, North Carolina. His most recent book is After Nature: A Politics for the Anthropocene (2015, Harvard University Press).}

Barack Obama's eight-year presidency changed utterly on 8 November 2016, when Donald Trump narrowly defeated Hillary Clinton in the contest to become his successor as President of the United States.

The ironies are cruel. Trump is an anti-Obama. The country's first black president, scion of a middle-class, mixed-race, globe-spanning family, will hand the White House to an America-first plutocrat whose campaign created a new version of white identity politics. Obama is deeply intelligent, reflective and deliberate, to the point of sometimes seeming hesitant or inhibited in public - a president who is all superego. Trump is a Republican id: impulsive and unapologetic offence are what you might call his leadership style. The Obama administration has been singularly ethical, going eight years under an opposition microscope with no plausible scandal. Trump has already made clear that he will be redefining presidential ethics as he spends the next four years building his global brand. At the end of Barack Obama's second term, with his approval ratings still over 50 per cent - he could almost certainly have beaten Trump, had he been constitutionally allowed to seek a third term - the defining thing about his presidency is that it ended with Trump's victory.

It isn't only the question of the White House, which the Democrats have recently considered their strong suit in national politics. Obama leaves his party as weak as it has been for a century, without control of either house, in danger of losing supreme court seats now held by elderly justices, and devastated in state governments, where Republicans have swept elections for the last decade. Yet it is hard to find a bad word for him, hard not to feel that he is the best of America, and that the country failed itself in falling from his political

"Although I think
his reputation will
only grow over
time, the 2016
election threatens
to dismantle
many of Obama's
achievements, as it
hands total control
of the federal
government to the
Republicans."

"Although I think only grow over time, the 2016 election threatens to dismantle many of Obama's achievements, as it hands total control of the federal Republicans." 
maturity and chastened hopefulness into a nativist tantrum and incipient kleptocracy.

\section{A PRESIDENTIAL BREATH OF FRESH AIR AND FAIRNESS}

I voted and volunteered for Barack Obama in both his presidential races. In 2008, I was one of the canvassers who spent days in South Carolina, where he won a dramatic victory in the presidential primaries after losing New Hampshire. In his candidacy, I saw something new in my lifetime: a way to speak of solidarity and fairness as youthful, vital and, maybe above all, American principles. The proof was not just in Obama's unique eloquence, which seemed an unheralded music after 16 years of Bill Clinton's sentimental sideshow-barking and George W Bush's silverback grunts, but in the tide of political energy that moved around him. We volunteers many of us young (then), but many others old enough to remember Robert F Kennedy before he was assassinated in 1968 - felt we had rediscovered the basic power of democratic citizens: to remake the architecture of our collective lives through peaceful, purposeful mobilisation.

It wasn't just a dream. Obama beat Hillary Clinton, whose nomination was just as anointed, and meant to be just as inevitable, in 2008 as in 2016. Then this black man, who shared his middle name (Hussein) with the ousted dictator of Iraq and whose last name was one letter away from 'Osama' (bin Laden), defeated John McCain, a decorated veteran, legitimate war hero and actually principled Republican. Obama won North Carolina, Virginia (which had not voted Democrat since 1976), and Indiana, which had been Republican since 1964. 2008: truly a year of wonders.

\section{DEMOCRAT REJECTION?}

And now, here we are. But what has this catastrophe to do with Obama, other than the fact that it will inevitably define the memory of his presidency? There is a vast amount of contingency in Trump's win. Hillary Clinton finished ahead by 2 million votes nationally, meaning she would have won in any normal democracy; only the arcane and indefensible electoral college, an artifact of the constitutional compromise of 1789, handed the presidency to Trump. In hindsight, the Clinton campaign made disastrous decisions: to all but ignore the upper midwest, where Trump won the contest; to concentrate on Trump's temperamental failings and offensiveness to liberal sensibilities, rather than his right-wing economics (evident in the campaign despite populist noises) and long history of mistreating and stiffing workers and small businesses. In other words, in a thoroughly populist year, the Clinton camp ran a non-populist campaign against a gifted demagogue. For all that, Trump barely won.

"It is hard to find a
bad word for him,
hard not to feel
that he is the best
of America, and
that the country
failed itself in
falling from his
political maturity
and chastened
hopefulness into
a nativist tantrum
and incipient
kleptocracy."

"It is hard to find a bad word for him, hard not to feel of America, and that the country failed itself in falling from his and chastened hopefulness into and incipient kleptocracy." 
But there was more than poor campaign choices. Throughout the 2016 campaign, political energy was concentrated in movements and candidates that squarely rejected the premises of Barack Obama's politics. These premises were two: the first more evident in his campaigning and touchstone speeches, the second in his governing. First was a redemptive American constitutionalism, a recurrent insistence that the arc of American history really does bend towards justice, if only Americans work to make good on their own principles: liberty and equality foremost. This is the language of Abraham Lincoln and Martin Luther King, and Obama spoke it better than anyone in his generation. It was, really, the nerve of his 2008 campaign, the refrain of his oratory, and the Sistine ceiling of his political imagination.

There is not a hint of this in Donald Trump's campaign. His America has nothing to do with the arc of justice. Its historical memory runs back as far as some ill-specified time when the country was 'great', forward to the next promised 'win'. But Trump is hardly alone.

Bernie Sanders's 'democratic socialist' populist campaign had no time for Obama's high-mindedness. Sanders spoke the language of class conflict and 'political revolution', solidarity and struggle. Outside the presidential campaign, the most vital political movement in the US today, Black Lives Matter, is in many ways a direct rejection of Obama's redemptive constitutionalism. Its focus has been on the ways white America has resisted redemption, on the continuities that link slavery, Jim Crow segregation, and the economic inequality, mass incarceration, and racially disparate police violence of today. From street demonstrations to its most influential text, Ta-Nehisi Coates's Between the World and Me (2015), this movement confronts American history as a broken thing that continues to break black bodies, and seeks to challenge it from outside, not within its own constitutional logic and rhetoric. Even Hillary Clinton, Obama's designated successor, lacks the music of his redemptive language and set it aside.

Obama's other strut, and the heart of his governing, was technocracy. He consistently deferred to established experts in economics, finance, the military and so forth. By and large, he also stuck to the deep technocratic assumption that there is a rough-and-ready 'public interest' that good government can achieve if it is only allowed to work efficiently and rationally. This has been the hallmark of American liberalism and progressivism (as we call our government-friendly centre-left tradition) for more than a century. It is to be contrasted with a focus on distributional politics.

It is obvious that the Sanders campaign put economic distribution alongside democratic renewal at the heart of its programme. It was the clearest response in 2016 to the new political awareness of inequality that followed the appearance of Thomas Piketty's Capitalism in the Twenty-First Century (2013), and, more importantly, to the lived experience of many Americans, of all ages but especially the young - experiences of economic uncertainty, anxiety, and stagnation. But

"In a thoroughly
populist year, the
Clinton camp ran
a non-populist
campaign
against a gifted
demagogue. For
all that, Trump
barely won."

"In a thoroughly populist year, the Clinton camp ran a non-populist campaign demagogue. For all that, Trump barely won. 
Trump's campaign is also intensely distributional, albeit in a centre-right, nationalist register: wealth and jobs for Americans, not the Chinese; public benefits for American retirees (we shall see how long that lasts), not for refugees or immigrants; tax breaks for those who understand themselves as deserving. This distributional politics has actually been at the heart of Republican campaigns for decades, and was crystallised in Mitt Romney's notorious remark that 47 per cent of Americans were on the take and had no interest in responsible government or fiscal discipline. But it was Trump's focus on the un-American undeserving that made it especially explicit and central. Here, too, Obama stands on a political island, the waters having washed away the ground around him.

In all of these respects, it may be that the cruel and defining last twist in Barack Obama's presidency is not personal, not even specifically American, but a symptom of world history. Something is afoot at the end of 2016 that was hardly hinted at in 2008: a pattern of nationalism, populism and political anger. Frequently, as in Trumpism and the Brexit campaign, it seems to combine intense democratic self-assertion with scepticism verging on nihilism about the capacity of existing states to do any real governing at all. Obama ran as a more optimistic sort of populist in 2008, but in hindsight he seems to have regarded that demotic triumph more as a qualifying exam than as his calling. His surprising diffidence about movement politics, his impulse to cool emotions rather than raise them, and his respect for institutions make him not just the anti-Trump, but Mr Anti-2016.

And yet. After all that, to repeat, he could probably have won a third term. Barack Obama, the insurgent of 2008, has come to stand for the idea that the system works, or can be made to work with enough effort. Many many Americans want to believe that, enough that they would have been glad to let him continue standing for it a while longer.

\section{FROM CAMPAIGN ERRORS TO A STRENGTHENING OF THE LEFT}

That does not make Obama an innocent bystander in the present catastrophe. He called into being the first, and one of the most hopeful, of the populist waves of the last decade, then turned his back on it once it had delivered him to power. He shared his party establishment's disdain for the Bernie Sanders movement when Sanders nearly repeated Obama's 2008 trick of beating an anointed Clinton, and generally failed to discern the lack of enthusiasm for Clinton or to save her self-defeatingly conventional campaign. If the Barack Obama of 2008 had meant everything he said, and felt it as his followers did, he might have had some sense that not all was as the pollsters and demographers assured him. On a deeper level, Obama did not show much inclination to fight his way out of the neoliberal, hawkish model of government that he inherited: from Obamacare to Afghanistan, he has rather tried to administer it in a more rational and humane fashion. Donald Trump will amplify

“It may be
that the cruel
and defining
last twist in
Barack Obama's
presidency is not
personal, not
even specifically
American, but
a symptom of
world history."

"It may be that the cruel and defining last twist in Barack Obama's personal, not even specifically American, but world history." 
the worst of that model while discarding the best of Obama's work within it, but he also managed, mostly on attitude alone, to profit from voters' frustration with it. Rising Obamacare premiums, frustration with available healthcare plans, and endless, pointless wars helped Trump, even though he will make all of these problems worse.

An unintended consequence of Obama's presidency has been the rise of a stronger American left than has been seen in nearly 50 years. There was something in the mere election of a liberal that created breathing room for radical impulses that, since 2001, had been concentrated on constitutionalist resistance to executive overreach and lawless war. In 2011, after three years of mostly patient post-crash suffering, Occupy Wall Street sprang up alongside the encampment movements of Madrid, London, Tel Aviv and elsewhere. The occupiers' slogan 'We are the 99 per cent' presented a curious kind of permission to commentators great and small to begin talking without apology about economic inequality - which had been growing for almost 40 years, mostly unacknowledged beyond the gadfly left. Around 2011, a small surge in radical ideas began, including the appearance of the pugnacious socialist-Marxian magazine Jacobin and smaller fellow travellers. There was new interest on campuses in political economy and radical ideas.

Then came the Sanders campaign, appealing to working-class and lower-income voters, young people and the highly educated, and, despite its notoriously weak performance among older African American voters, decisive majorities of young voters of colour. It was the year's best chance to turn the wave of populist energy in an anti-racist, solidaristic and genuinely egalitarian direction. A missed opportunity for now, it may not be done yet. It will not be Barack Obama's forces that save his legacy, if it is saved at all.

\section{"An unintended consequence of Obama's presidency has been the rise of a stronger American left than has been seen in nearly 50 years."}

\section{HOPE HANGOVER}

\section{Samuel Moyn is professor of law and history at Harvard University.}

Barack Obama has been the best president of my lifetime.

The trouble is, that isn't saying much. If his time in office bears a lesson for the future, it is the need to move towards what we might call 'realistic idealism'.

Obama's calm could not compensate for the gridlock to which he deferred and the injustice he had to tolerate. And that is because the sort of idealism he represented has already reached its limits and begun to be replaced.

On the night he was first elected, Obama explained that his victory was 'not the change we seek. It [was] only the chance to make that change.' But by and large, the chance was missed. Allergic to all but 
rhetorical mobilisation, he put too much stock in supposedly postpolitical expertise. Outside of election time and mourning for national tragedies, Obama rarely tried to connect to his voters, squandering the hope he famously elicited, except for an occasional rhetorical high that weakened each time.

A couple of years ago, I guessed that Obama's primary legacy would be his destruction of political idealism. Given that the Bernie Sanders candidacy took the country by storm soon after, it was a premature claim, to say the least. Even though he was bitterly criticised as a dreamy idealist himself, Sanders actually showed a different tendency at work.

The tide of hope for Obama in 2008 was different from the swell of enthusiasm for Sanders in 2016. The former was far larger and it worked like a daydream: it provided a lovely escape. By contrast, Sanders's idealism took the form of a partisan jeremiad. Sanders did not imply a quick fix or suggest that everyone really agreed if only politicians would stop misleading them. Imperfectly but better than any other candidate, Sanders addressed the core concerns of Black Lives Matter, without forgetting the undereducated white Americans whose class agony has misled so many into supporting Donald Trump and scapegoating other victims rather than participating in a transracial majority that would advance their interests.

Sanders's remedies were also a kind of realistic idealism. The solutions called not for easy unification of the American people but, in the spirit of Franklin Roosevelt, forcing the rich into a collective venture in the society they currently rule from on high and as if from outside. This kind of idealism is riskier. It calls for more, not less, division, refusing to offer false rhetorical healing. It does not promise to overcome difference with words but to undo it with policy.

People will differ over whether or not they want a realistic idealism. Some people prefer the purity of abstract promise, whether for their lives in this world or the next. But Obama's true significance is that he has taught many of his followers to rethink what sort of hope they want. It can be beautiful but diversionary and evanescent, or it can be divisive and uncertain but real.

Now that Donald Trump has been elected president, a frightened sense of threat has understandably crept in. Having entered by inviting hope, Obama is leaving by symbolising normality. Fear of the state, not debate about how to turn the state to help ordinary people, predominates. And fair enough: the risks under Trump and his associates are plain. But there is also a great risk that, in the confusion, a necessary debate about the future of our idealism gets lost as the sense of emergency thrusts itself into the foreground. If we revert to a hard-bitten realism about the bare fundamentals of a free society to rally around in the storm, not only will we fail to be ready when it passes, but we will have no vision to offer those who have thrown in their lot with the charlatan.

\section{"Sanders's remedies were also a kind of realistic idealism... This kind of idealism is riskier. It calls for more, not less, division, refusing to offer false rhetorical healing."}




\section{OBAMA AND THE POTENTIAL, AND LIMITS, OF LIBERALISM}

\section{Richard Yeselson is a contributing editor to Dissent magazine.}

A horrifying orange meteorite seems likely to eviscerate Barack Obama's policy legacy. The election of Donald Trump, and, just as importantly, the unified control of the American government by a hyper extremist and partisan Republican party, means that Obama's major policies - and indeed a good deal of the already truncated US welfare state that predates him - could well be extinguished. More important for the future of the planet, Obama's efforts to slow down climate change are also likely to be ignored at best (the Paris agreement) or simply reversed (presidential initiatives to regulate carbon emissions in the US).

Whether all of this happens or not depends on the byzantine workings of congress and whether the, um, mercurial Trump actually cares to ratify its decisions. Those decisions will likely include some effort to repeal, or at least gravely damage, Obamacare, the president's incremental, flawed but nevertheless significant effort to reform the American healthcare system, one that has provided insurance to 20 million Americans. Republicans are also looking forward to gutting the Dodd-Frank Act and other efforts to regulate banks and Wall Street, as well as the consumer financial protection bureau, a project driven by the liberal left senator Elizabeth Warren, whom the executive class despises. Trump's circle of plutocratic buddies should find all of these changes to be excellent ideas indeed. It is true that Eisenhower did not roll back FDR's New Deal; neither did Churchill roll back Atlee's NHS. But, even though today's Republicans claim to admire both those men, they don't make conservatives like Ike any more in the US.

Trump's appointment of Jeff Sessions, an extremist remnant of the pre-civil rights Jim Crow South, as the nation's attorney general will gut the justice department's civil rights enforcement. This includes support for African American and Latino voting rights, which Republican state governments around the country have sought to impede by making it more difficult for those without voter IDs or time off on election day to vote. This might have an increasing impact on the Democratic party's ability to win office at the state and national level for years to come. Regardless of its political impact, in a nation in which African Americans have died for the right to vote, it is morally despicable.

Even easier for Trump to reverse will be Obama's executive orders, issued as a last resort because of the Republican obstruction to his legislative agenda, which we Americans attribute to 'divided government'. Government is now divided no more and the Republicans will, effectively, come close to running a parliamentary

\section{"A horrifying orange meteorite seems likely to eviscerate Barack Obama's policy legacy."}


programme. Thus, for example, Trump can, owing to a law a Republican congress passed at the beginning of George W Bush's administration, simply delete several of these executive orders that would raise the wages and improve the working conditions of millions of workers who are employed by companies that do business with the federal government. Trump's purported populism - which he also displays by fighting a union-organising drive at his Las Vegas property - does not quite include raises for underpaid Americans during a time of great income inequality.

Again, all of this hangs in the balance. It is possible that the Republicans will botch the logistics of gestating their libertarian obsessions or that Trump will double-cross the speaker of the house, Paul Ryan, the genial anti-redistributionist fanatic with whom he has had a tense interaction. It is already clear that, even on his own authoritarian terms, Trump has no idea what he is doing. But the Republicans are implacable and, in that Trump is ignorant and indifferent about almost every element of public policy, he is as much likely to give them what they want as not.

Assuming that much of this happens, Obama's policy legacy will - astonishingly given the obvious historic nature of his presidency amount to very little. So what will Barack Obama leave behind?

Three important things, I think. First, Obama constantly appealed to his fellow citizens that the country must redeem the promise of the universalist aspirations of its founding credo, 'All men are created equal', duly revised to account for subsequent African American and feminist struggles for that same equality. His speech at the 50th anniversary of the civil rights march at Selma, Alabama in March 2015, in the face of a racist assault by police, powerfully embodies his understanding of the great sweep of American history. This story is a kind of cosmopolitan civic nationalism, a counter-narrative to the ethno and racial nationalism of the Trumpists and much of the Republican party. It will be drawn upon again and again to inspire and mobilise many over the years to come.

Second, this story of the continued struggle for social justice and national perfectibility has given many young, non-white and working-class leftists a bit of space to generate their own movements. Black Lives Matter, the 'Fight for \$15 [per hour wages]', Occupy Wall Street and, of course, the Sanders campaign (even as Obama himself supported his more mainstream colleague Hillary Clinton) have all emerged during the Obama years. So as with FDR during the 1930s and JFK at the start of the 1960s, Obama has been a democratic president - a breed often cautious to propose reform - who has enabled more militant expressions of political change to emerge. Liberals aren't leftists, but nor are they conservatives who tend to actively repress the left - there is synergy between liberals and leftists, which its warring antagonists don't always appreciate. These movements will be challenged by Trump's belligerence, but most of them have already caught hold and

\section{"The Republicans are implacable and, in that Trump is ignorant and indifferent about almost every element of public policy, he is as much likely to give them what they want as not."}


are ready to continue to fight. Their efforts have already moved the Democratic party to the left on matters of economic redistribution (Clinton herself was a very different politician from her husband), and this will be important in appealing to a working class of whites and non-whites alike in the future.

Finally, Obama's post-partisan language - assumed to be in bad faith by the right and mocked as weak by the left - actually served to expose the revanchist hysteria that courses through much of the Republican party. (There are some principled conservative writers and intellectuals trying to resist this tendency but, so far, well... note who is the president-elect.) To name just a few central examples: the sheer hysteria about a modest healthcare bill - frequently labelled 'the death of freedom' by GOP politicians; the insane efforts to label Obama un-American (led by Trump!) and a dangerous Muslim; and, as important, the procedural radicalism of the congressional Republicans, engineered by the party's top strategist, senate leader Mitch McConnell (shutting down the government, insisting on a supermajority requirement for every bill, denying Obama the right to fill the supreme court vacancy caused by the death of Justice Scalia, and much else).

On the one hand, the Democratic party is at its weakest position since 1928. It will have to figure out what it stands for and how to regain power when certain structural conditions under the US constitution tilt in favour of the Republicans. On the other, for four years Obama tried to work with the Republicans in good faith, but probably naively, before eventually concluding that he was, in fact, naive. Now the Republicans control the entirety of the government and will move the courts in their direction too. The paradoxical effect of Obama's proffered hand being spurned will be that as he leaves office more popular than ever, the American people may see that in choosing Trump as his replacement they have reaped the whirlwind. Donald Trump is a unique monster, but he was spawned in a Republican laboratory.

“The paradoxical
effect of Obama's
proffered hand
being spurned
will be that as he
leaves office more
popular than ever,
the American
people may see
that in choosing
Trump as his
replacement they
have reaped the
whirlwind."

"The paradoxical effect of Obama's proffered hand being spurned will be that as he popular than ever, the American people may see that in choosing replacement they whirlwind."

\section{OBAMA AND HEALTHCARE}

\section{Elizabeth Bruenig is an assistant editor at the Washington Post, and has contributed to other publications on ethics, politics, culture and Christianity.}

With the 2016 election already consigned to memory, some Americans have already begun to regard President Obama - not yet out of office - with a sense of nostalgia. It's not difficult to see why. Obama will leave the White House with higher approval ratings than ever (CCN/ORC poll), while the incoming president will take his place with fewer popular votes than any winner in over 100 years and record high unfavourable ratings (Gallup poll). The clarity of hindsight also casts the uncertainty attached to Trump's nascent administration in a fearsome 
light: it's obvious to us now that Obama led the nation through a trying but peaceful eight years, but it's difficult to even guess what Trump will mean for the future.

One of Trump's principle promises while running for president was that he would undo Obamacare, the unofficial title of the Patient Protection and Affordable Care Act, a federal statute Obama enacted in 2010 and spent the remainder of his presidency defending. It has been fought in states and courts and hotly contested within conservative media, and has been dubbed a Trojan horse for socialism by Republican lawmakers. Obamacare may well have helped win Trump the election.

Some 81 per cent of Trump voters were unhappy with Obamacare (ABC figures), and of voters displeased with the Act, 80 per cent broke for Trump (NBC figures). In late October, the Obama administration announced that premiums for mid-level plans could rise some 25 per cent in 2017, and while much of the cost spike would be absorbed by subsidies, that's cold comfort to those already distressed over the tax burden of an often unwieldy and complex programme. Indeed, at the end of Obama's term, millions are still uninsured in states without expanded Medicaid coverage (the state and federal programme that provides health coverage for those on a very low income), others have been left clinging to 'bronze plans' with absurdly high deductibles that leave families functionally uninsured, and in some districts so many insurance companies have pulled out of the exchanges that there is no choice left to citizens. With Republicans taking control of the White House and both houses of congress, it's hard to imagine that a brighter future for Obamacare lies on the horizon.

Some of the programme's misfortunes are political: Conservatives fought Obamacare and made it difficult for Democrats to enact all the provisions they had planned. But others are structural, and were built into it from its inception. It was always aimed at sealing gaps in the employment-based American healthcare regime, and though its supporters promised it would provide an 'off-ramp' to that system, the exit never arrived. This meant that rather than vastly improving lives and thus building an automatic constituency of support to sway politicians towards keeping the plan in place, Obamacare vexed millions and provided conservatives with a glaring vulnerability to exploit.

Ultimately, though, centrist Democrats happy with Obamacare's limited approach to solving problems with the pre-existing system may not be the biggest political losers in the coming years.

Though they face the destruction of Obama's namesake programme and with it, much of his legacy - the programme's demise may prove even more damaging for the left. While some American politicians have rallied for a Medicaid-for-all system that would institute a singlepayer programme in the United States, this leftward proposition failed in the 2016 Democratic primaries, in part because many Democrats insisted that it would entail scrapping Obamacare. Rather than momentum-building for a single-payer system, it's safe to presume 
Democrats will be doing little more than defending the remnants of Obamacare for the foreseeable future. And the association between Obamacare's snags and what Fox News and others have dubbed 'socialised medicine' will very likely doom agitation by the left for a more expansive programme for years to come. Prospects for a push towards a single-payer system would have been very dim under a Clinton administration, and under a Trump administration they are essentially non-existent.

Of course, there will be many hurt by rolling back Obamacare, though it isn't yet clear which parts Trump will set his sights on and which he will spare. Those who lose coverage will be in a much more distressing position than those whose political hopes have been frustrated by the way the programme unfolded. But as Obama moves on to the next phase in his life, the Obamacare portion of his legacy appears to hold little promise: the right detests it, the centre concedes that there is much about it that needs repair (repair that now appears unlikely to happen), and the left has little reason to hope it may give way to a more progressive American healthcare system. If it goes down in history as a success, it will only be because what comes next may be bad enough to inflict amnesia about how we got here.
"The association

between

Obamacare's

snags and what

Fox News and

others have

dubbed 'socialised

medicine' will

very likely doom

agitation by

the left for a

more expansive

programme for

years to come."

\section{OBAMA, LIVING STANDARDS AND THE FUTURE}

\section{Lane Kenworthy is professor of sociology and Yankelovich chair in social thought at the University of California, San Diego. His most recent books are How Big Should Our Government Be? (Bakija et al, University of California Press, 2016) and Social Democratic America (OUP USA, 2014).}

The chief reason Donald Trump received so many votes in the US presidential election is that most Americans are firmly attached to their preferred political party and each party has the support of roughly half of the electorate. Most Republicans will vote for the Republican candidate no matter how objectionable he or she may be, which guarantees that candidate about half of the votes. A secondary reason is that a significant number of white Americans without a four-year college degree - 'workingclass' whites - seem to have wanted a president committed to changing the country's economic and/or social direction. Trump won this group by a margin of almost 40 percentage points. That's a stunning number and a significant increase from the margins in previous elections. 
What exactly do these working-class white Americans think has gone wrong? Some possibilities:

- Frustration at perceived economic decline. In 2014, white persons aged 25-54 without a college degree were twice as likely as African Americans to say their standard of living was much worse or somewhat worse than their parents'.

- Frustration at lack of economic improvement. Wages have been stagnant for the lower half of American earners since the late 1970s. For men without a college degree they have decreased. Household incomes have increased, but not much, and since 2000 they too have been stagnant.

- Worry due to economic insecurity - fear of losing a job and not finding a comparable replacement, fear of losing one's home to foreclosure, fear of poverty in retirement.

- Frustration at the high cost of childcare, health insurance, housing in an area that's safe and has a good state ('public') school and college.

- Resentment at growing economic inequality. Those with a college degree have been doing fine, the rich even more so.

- Resentment at groups who receive particular types of government help, from social assistance to healthcare to disability benefits to 'affirmative action' (positive discrimination).

- Frustration at loss of status. This is especially pertinent for working-class men, whose identity used to be centred on having a stable, solid-paying, full-time job in a 'male occupation'.

- Frustration at neighbourhood and small-town urban decay fewer good jobs; less attendance at religious services; schools and infrastructure decaying due to revenue decline, which spurs population decline, which furthers the revenue decline; more people misusing drugs such as meth, opioids and heroin. This is in sharp contrast to the big cities - even some that were in bad shape a few decades ago, like New York and Pittsburg - which seem to be doing very well, with growing populations, declining crime, plentiful restaurants, well-kept parks and new housing.

- Discomfort with social and cultural modernity - the embrace of racial and ethnic diversity, openness to non-traditional family structures and sexual orientations, political correctness, and the ascendance of secularism.

- Resentment at being viewed as ignorant, simple-minded, backward, blindly religious, intolerant, 'deplorable' by economic, cultural, media and governmental elites.

- Distrust of politicians who argue for staying the course. They must be in the pockets of the rich and powerful or the well organised. Perhaps they are lining their own pockets. 
The Obama administration worked hard to improve the economic wellbeing of ordinary Americans and it achieved some notable successes, among them: helping to prevent a 1930s-level economic collapse (the 2009 stimulus) and strengthening regulations on the financial sector to reduce the risk of future financial crises (the DoddFrank Act), passing a healthcare reform that increased the share of Americans with health insurance from 85 to 91 per cent and slowed the growth of health costs (the 2010 Affordable Care Act), investing in infrastructure (stimulus), expanding the earned income tax credit (stimulus), appointing a federal reserve chair (Janet Yellen) committed to pursuing not just low inflation but also maximum employment.

In the presidential campaign, Hillary Clinton and Bernie Sanders offered additional proposals: affordable early education, paid parental leave, paid sickness leave, reduced cost of college, more investment in infrastructure, rule changes to make it easier to form and sustain labour unions, a higher federal minimum wage, a tax incentive for firms to adopt profit sharing.

All of these would be helpful. But they are not, alone or in combination, likely to bring back the lifetime job with a middle-class salary that at least some, perhaps many, of the non-college-educated white Americans in Pennsylvania, Ohio, Michigan and Wisconsin yearn for.

To speak to that yearning, Sanders and Clinton, like Barack Obama in 2008, argued for a tougher approach to trade policy, suggesting that American workers could get back some of the manufacturing jobs that have moved to China, Mexico and other lower-wage countries in recent decades. But Obama wasn't really committed to restricting trade, and neither was Clinton. Whether Donald Trump genuinely favours doing so is anyone's guess, but he made the case with gusto, so voters may have been more likely to believe him.

What should be the progressive strategy for working-class Americans in small and medium-sized towns and cities that have lost manufacturing jobs? Some elements, like education, (re)training and infrastructure investment, are uncontroversial. But let me highlight three that, while a tougher sell for political candidates, I hope progressives will be increasingly willing to confront.

First, we should embrace trade with low-wage nations. It benefits us as consumers and it boosts the living standards of people in those countries who are much poorer than we are. Progressives want the world's less fortunate to have not only freedom and democracy but also economic prosperity, and manufacturing jobs are very helpful in this pursuit. In any event, manufacturing employment has been shrinking steadily in all rich nations since the 1970s. As with agricultural jobs in earlier decades, this is due as much to automation as to globalisation. When transport costs increased a few years ago because of higher oil prices, some manufacturers moved production from China back to the United States, but often to factories operated largely by robots.

\section{“The Democrats" proposals to raise living standards are not likely to bring back the lifetime job with a middle-class salary that at least some, perhaps many, of the non- college-educated white Americans in Pennsylvania, Ohio, Michigan and Wisconsin yearn for."}


Second, using public resources judiciously means resisting the temptation to spend to the hilt in order to keep a dying town afloat. Sometimes the best course of action will be for people to move elsewhere, to where the jobs are, even though that means leaving friends, neighbours and community.

Third, one of the best strategies for revitalising a declining area is to attract population inflow. Here a particularly likely source is immigrants. The case for immigration rests not just on appreciation of diversity and concern for the least well-off: it's also based on narrow self-interest.

\section{OBAMA AND CLIMATE CHANGE}

\section{Joss Garman is the political director of the Syria Campaign, and a former director at Greenpeace UK and the Institute for Public Policy Research (IPPR). He advised Lisa Nandy MP in her role as shadow energy and climate change secretary.}

Accepting his nomination to be the Democratic presidential candidate on 3 June 2008 Barack Obama told the crowds, 'This was the moment when the rise of the oceans began to slow and our planet began to heal'. But was it?

NASA reports that 2016 is on course to be the hottest year on record, and the last few months have seen Arctic sea ice levels at lows unprecedented for this time of year (data from the National Snow and Ice Data Center). Yet for the first time since the start of the industrial revolution the output of global carbon pollution has stalled, investment in clean energy is at an all-time high, emissions from the US are at their lowest level for two decades, and in the Paris agreement the world has its first ever legally binding global deal to address climate change, with commitments from all of the biggest economies including China.

President Obama can probably take more credit for this progress than anybody else, but it wasn't always clear that this would be his legacy. His strategy for delivering pollution cuts inside the US seemed to falter in his first term in office after the complete failure, in the face of an intransigent congress, of his administration to introduce his proposed European-style carbon trading scheme. Against the backdrop of the global financial crisis, this defeat sucked hope out of COP15, the UN climate change talks held in Copenhagen in 2009, and cast extreme doubt that the world would ever manage to agree to any global action at all. An international agreement was left looking near impossible when the Chinese and other major emerging economies simply refused to follow a cleaner growth pathway until the US agreed to do the same. 
Through an approach of delivering a credible domestic action plan, together with intensive diplomacy by Secretary Kerry, a deal was finally struck between the two largest polluters in the world, which broke the deadlock that had dogged the negotiations for 20 years. This was instrumental in enabling the Paris summit, COP21, to be a success. Ahead of the historic conference in December 2015, Obama told one visitor to the Oval office: 'I'm dragging the world behind me to Paris'.

And so he did. The US-China deal, struck just months before COP21, saw a commitment from Beijing to build an additional 800-1,000 gigawatts of nuclear, wind, solar and other zero-emission generation capacity over the next 15 years - more than the capacity of all the coal-fired power plants that exist in China today and close to the total current electricity generation capacity of the United States. The evidence of the seriousness of that Chinese plan can now be seen from the changing facts on the ground already being witnessed. The country's coal use has likely peaked already (according to analysis by leading economists including Lord Nicholas Stern), and China is now investing more than any other in clean energy technologies: more than US\$100 billion in 2015 alone.

While mounting pressure from the residents of smog-filled Chinese cities and the increasing quality and affordability of renewable technologies were also key factors in securing this progress, the scale of China's commitment can be seen as a monument to the success of President Obama's diplomatic efforts, which in turn were dependent upon the changes he was eventually able to drive through at home through his personal leadership.

In a hugely symbolic move in the weeks ahead of the Paris summit, Obama vetoed the proposed Keystone pipeline, which would have carried the dirtiest oil on Earth from the tar sands of Canada into the United States for refining and export to global markets. This followed major national protests, and a warning from NASA director Professor James Hansen that its construction could mean 'game over' for the climate.

But more consequential in emissions terms were Obama's successful doubling of vehicle fuel efficiency standards and the reforms to the rules governing the US power sector. In a landmark supreme court ruling Obama won acknowledgment that carbon dioxide is a pollutant requiring regulatory action by the Environmental Protection Agency in order to protect public health. This ruling formed the basis of his new clean power plan, which allowed him to use executive action to bypass congress and to require that every state needed to develop a preferred strategy for lowering emissions output in their area to specified levels. Together with tens of billions of dollars in public investment in clean energy that Obama injected through his stimulus package, this locked the US coal industry into the death spiral that was taking place anyway as a consequence of the country's shale gas revolution. In the Obama

\section{"The scale of China's commitment can be seen as a monument to the success of President Obama's diplomatic efforts."}


era, one-third of the US coal fleet was retired, and half is expected to have closed by the end of 2017.

This remarkable shift in energy investment, under way right across the United States, means that even if president-elect Trump does away with Obama's clean power plan, as he has said he will, the US may still meet the country's Paris agreement commitments. One analysis suggested the US's targets could be met 15 years early, such is the pace of the changing reality (by Julie Kashen for Politico Magazine). As Secretary Kerry told the COP22 UN climate summit in Marrakech in November 2016, 'Market-based forces are taking hold all over the world... None of us pretended that in Paris the agreement itself was going to achieve two degrees. What we knew is we were sending that critical message to the marketplace, and businesses have responded.'

With just days left in office, Obama still seems focused on what environmental protections he can lock down before Trump's inauguration. In late November he announced that he was putting huge areas of the sensitive Arctic Ocean off limits from oil and gas exploration (as part of a new five-year plan under the Bureau of Ocean Energy Management). This further boosts his achievement of being the US president to have protected more acreage of public land and water from industrial development than any other in history.

The scale of the environmental damage to be inflicted by a Trump administration swamped with fossil fuel lobbyists remains unclear, but as Obama said of the international climate effort in an interview with the New York Times in May 2014, 'It's not going to happen as fast or as smoothly or as elegantly as we like, but, if we are persistent, we will make progress.'

\section{OBAMA'S RHETORIC}

\section{Alan Finlayson is professor of political and social theory at the University of East Anglia.}

'If there is anyone out there who still doubts that America is a place where all things are possible, who still wonders if the dream of our founders is alive in our time, who still questions the power of our democracy, tonight is your answer.'

Barack Obama, presidential victory speech, 4 November 2008

'Working together, we will begin the urgent task of rebuilding our nation and renewing the American dream. I've spent my entire life and business looking at the untapped potential in projects and in people all over the world. That is now what I want to do for our country.'

Donald J Trump, presidential victory speech, 9 November 2016 
To persuade people in matters of politics and public affairs to inspire and move them to action - one must first have a grasp of the peculiarities of the particular humans to whom one is speaking. Rhetoric is not primarily about turns of phrase and rhythmic repetition. It is about making use of 'common opinion' - things most people believe to be true. It connects a proposition (to support a bill, raise taxes, start a war) to sentiments, values and understandings already shared by the audience. It shows that some new plan or idea is similar or connected to something with which we are already familiar, making it thinkable in some specific way. In so doing, rhetoric makes manifest some part of the culture and character of a people, applying it to the problems of the present, testing its mettle.

When the novel proposition is a candidate, then the candidate has, in some way, to connect themselves to something the audience already knows and thinks and to something in its character. Only then can that candidacy become thinkable and meaningful. As the sociologist Jeffrey Alexander puts it in his (recommended) account of Obama's rise, The Performance of Politics (OUP, 2011), one of the things that politics is made of is a public stage upon which political actors (in all senses of that word) 'project performances of their reasons'. They embody a claim about human affairs - some set of shared beliefs, feelings, moods and meanings - and act as protagonists in our social drama. They are 'exemplifications of sacred religious and secular texts'. At elections, rival candidates perform different propositions. They activate and amplify different kinds of belief and participate in a societal dispute about which parts of our collective character we should cultivate and express.

At such performances Barack Obama was a master. In his 2004 address to the Democratic party convention Obama announced his presence on the stage as 'pretty unlikely' before speaking of his father - 'he grew up herding goats, went to school in a tin-roof school', and his mother, the Kansas-born daughter of an oil rigger and soldier. $\mathrm{He}$ evoked the old American story of social mobility, expanding it into a newer story of cultures meeting and melding. Obama's grandparents had a dream that they worked hard to realise; his parents had dreams they too worked hard to fulfil, and now Obama on stage in front of fellow Democrats was the fulfilment of that dream, even as he dreamed of the future for his own children. 'I stand here today, grateful for the diversity of my heritage, aware that my parents' dreams live on in my precious daughters. I stand here knowing that my story is part of the larger American story, that I owe a debt to all of those who came before me, and that, in no other country on Earth is my story even possible': the American exception and the dreams that it is made on, materialised before the audience in the body and words of Barack Obama.

By 2007, Obama's 'unlikely presence' had turned into an 'improbable quest' for the nomination. In 2008, after a better than expected loss

\section{"Rhetoric makes manifest some part of the culture and character of a people, applying it to the problems of the present, testing its mettle."}


in New Hampshire, it was 'our improbable journey'. Listing and so integrating his diverse supporters into one unified campaign, Obama made the 'impossible odds' they faced equivalent to those overcome by 'generations of Americans' - slaves and abolitionists, immigrants and pioneers, organised workers and suffragettes, Kennedy and King. The pairings unite, the list makes time into one movement (the 'arc of the moral universe', which 'bends towards justice') at the culmination of which is the Obama campaign itself: 'Yes. We can.'

The highest achievement of this art was his March 2008 speech 'A More Perfect Union', delivered as senator. Here, on the backfoot over the politics of race, Obama modified his story so that it embodied not just the promise of America but the trauma too the 'stain', the 'original sin of slavery'. Now the improbable thing is the American experiment in democracy itself - an experiment still under way and which, though fraught, could succeed in the form of this improbable campaign. Significantly, that speech ended with the story of 'a 23-year-old white woman named Ashley Baia', working for the campaign organising an African American community. At an organisers' meeting, Obama told us, an elderly black man explained that he was there not for healthcare, the economy, education, the war or Obama himself but 'because of Ashley'. In 'that single moment of recognition between that young white girl and that old black man', Obama implied, we glimpsed the perfection of the Union that his campaign promised. And so, in his victory speech in 2008 , electoral success was proof of the living dream, the realisation of the founders' vision, the instantiation of democracy itself. Who, indeed, could doubt it?

Watching Trump's victory speech eight years later we should be struck at first by how similar it is to Obama's. It lacks the fluency, of course, but it too celebrates a movement that has culminated in victory and that builds its promise around the American Dream: a promise that Trump managed (improbably) to embody more successfully than his opponent. But it is not the same dream. In a precise way, Trump's performance is the opposite of Obama's. Where Obama sought to embody the potential success of the American dream, Trump embodied recognition of its loss. His campaign organised itself around the idea that the dream required not fulfilment but rescue - not making the US great but making it great again.

In the quote that forms an epigraph to this essay, Trump announces a common project to rebuild and renew. The implication - the common opinion shared by his audience - is that the US has gone wrong, is broken, its potential untapped. Trump's campaign was dedicated in ways often unnoticed to speaking of sorrow and of loss - of jobs, security and dignity; of children killed in badly fought wars against dictators abroad and drugs at home. But having evoked such experiences, common to many in the audience, the rhetoric turned to allocation of blame: China, NATO, establishment politicians, 'crooked' Hillary.

The rhetorical performance of Trump is the dark dialectical antithesis of Obama's. Obama represented himself as a fulfilment of the

"Where Obama
sought to embody
the potential
success of the
American dream,
Trump embodied
recognition of its
loss. His campaign
organised itself
around the idea
that the dream
required not
fulfilment but
rescue."


American dream; Trump's political career began as an attempt to prove that Obama was not American at all. Obama's story was self-proclaimed as 'unlikely, 'improbable' - and Trump claimed it was literally so. Where Obama made himself, and remained, so very presidential, Trump - with all the bluster and offence - become the epitome of the un-presidential, in a performance that was thus an implicit critique of the aloofness of the office itself. Obama's was a promise of racial unity. Trump reverses the meaning of that concept so that it stands for radical racial division, immigrants and others taking the country for themselves.

At a more fundamental level Obama used his personal story as the script for the performance of an 'exemplar': one who stands out as indicative rather than exceptional. He dissolved his uniqueness into the uniqueness of the country as a whole, which was then reflected back at an audience which recognised itself, its own promise, its own dream, its own historical mission. The Trump script was about the exceptional - the huge, the amazing, the most - not the exemplary. He performs himself, the businessman, the one who sees untapped potential, the one who stands out and stands apart from the mainstream. He is the one whose words do not belong to the office of president because his words are his own, just as his money is his own and he is his own man.

But - and this is very important - Trump did not project his image of himself directly at his audience. They were not invited to be supplicants to his greatness. His rhetoric does not simply tell his audience how great and wonderful they are but magnifies their sense of themselves as exceptions to the rule in the contemporary US and performs the projection of that being-excepted outwards at the others who are to blame. Audiences can vicariously enjoy Trump's aggression towards others, his mockery and his abuse. 'Hope is a joy not constant, arising from the idea of something future or past about the issue of which we sometimes doubt' wrote Spinoza. Obama's rhetoric, for its audience, inspired just such a joy in the face of uncertainty. 'Hatred', wrote Spinoza, 'is sorrow with the accompanying idea of an external cause'. Anger is the desire to injure those we hate and 'Derision is pleasure arising from our conceiving the presence of a quality, which we despise, in an object which we hate.' Hate, anger and derision - these are the emotional coordinates Trump's performance enables his sorrowful audience to experience.

Rhetoric succeeds by connecting new propositions to something an audience already believes. But political actors, movements and speechwriters choose which audiences they speak to and which of the many things a people believes should be appealed to. They choose which parts of our character to perform and promote. It is possible to win by appealing to particular constituencies, directing their sorrow at outsiders and giving them the feeling of power that comes with anger and derision. But it is also possible (or so progressives must believe) to seek to appeal to - what Obama in

“Trump's rhetorical
performance is the
dark dialectical
antithesis of
Obamas. Obama
represented
himself as a
fulfilment of the
American dream;
Trump's political
career began as an
attempt to prove
that Obama was
not American
at all.”

“Trump's rhetorical performance is the dark dialectical antithesis of Obama's. Obama represented fulfilment of the American dream; Trump's political career began as an that Obama was not American at all." 
his last state of the union address called - 'our better selves'. Or, to our 'grace', as he referred to in his eulogy to Clementa Pinckney, the Democrat state senator killed in the 2015 mass shooting at a Charleston church:

'... an open heart. That, more than any particular policy or analysis, is what's called upon right now, I think - what a friend of mine, the writer Marilyn Robinson, calls "that reservoir of goodness, beyond, and of another kind, that we are able to do each other in the ordinary cause of things". That reservoir of goodness. If we can find that grace, anything is possible. If we can tap that grace, everything can change. Amazing grace. Amazing grace.'

\section{OBAMA'S COMMUNICATION LEGACY}

\section{Julia Azari is associate professor and assistant chair of the department of political science at Marquette University. She is the author of Delivering the People's Message: The Changing Politics of the Presidential Mandate (Cornell University Press, 2014).}

As we plan for an unexpected and unprecedented presidential transition here in the United States, we should also contemplate the legacy that President Barack Obama has left behind. His presidency was historic and extraordinary in some ways, ordinary in others. But one area in which Obama's innovations will have lasting impact is in his approach to communication.

Presidential communication is an essential facet of the office: it informs national leadership and shapes the ideology of the party the president leads. These possibilities are especially critical to understanding the impact of Obama's communication legacy for presidential politics, and for anticipating the presidential politics to come.

Obama's communication legacy has been innovative in several ways. He built on a legacy from past presidents of adapting contemporary forms in order to democratise the presidency. As presidential power has increased and the way that citizens understand that power has become, on balance, more sceptical and more polarised, presidents have endeavoured to soften their images in a number of ways. They have used visual rhetoric, appearing in casual attire. They have used humour, addressed audiences directly and intimately, and told stories about their own backgrounds or those of others.

Obama took each of these methods to new levels. His appearance with Zach Galifianakis on the actor's online mock talk-show Between Two Ferns showed the president trading barbs with a dour and quirky comedian. His interaction with comedian Marc Maron (in June 2015) allowed him to contemplate at length the larger questions of American democracy and racial history.

\section{"Hate, anger and derision - these are the emotional coordinates Trump's performance enables his sorrowful audience to experience."}


It is perhaps in the area of race that Obama's communication legacy will be most fraught and unwieldy. Several scholars have noted that Obama invoked 'respectability politics' in his early rhetoric about the African American community, drawing on frameworks offered by figures like Bill Cosby, who insisted that black culture and behaviour were partially responsible for the community's disadvantaged status (for example, see The Race Whisperer by Melanye T Price, NYU Press, 2016, and The Price of the Ticket by Fredrick C Harris, OUP, 2012). By virtue of being part of that community, Obama could criticise it in ways that would have been off-limits for a white Democratic politician. Obama, as both candidate and president, was also able to talk about race in personal terms, invoking his experience with members of his multiracial family and uttering the famous line, 'If I had a son, he'd look like Trayvon Martin' (the 17-year-old African American fatally shot in Florida by a neighbourhood watch volunteer in 2012).

Mixing his style of casual, democratised 'real talk' with observations on race has left a puzzling roadmap for any white successor. Writing in September 2016, I predicted that the politics of the Obama years had left Hillary Clinton with a racially divided polity and a limited rhetorical script. This is not, of course, the situation that has come to pass.

Instead, the 2016 election has resulted in president-elect Trump. Like Obama, the president-elect has viewed his charge as one to talk about race in plain and authentic terms. But it is safe to conclude for now that Trump speaks to a very different audience. His descriptions of US cities have none of Obama's grasp of history or nuance.

It is likely that president-elect Trump is about to learn several lessons about communication that Obama also learned upon taking office. First, setting the bar high for authenticity is a double-edged sword. Promising honesty and transparency to voters - even implying it establishes expectations about openness. These expectations do not stop at the boundaries of the formal office: they extend to personal and financial dealings. The race implications are especially dire here: some of the president-elect's supporters have promoted the notion that he will 'make America white again'. These are not, needless to say, normal expectations for a modern politician about to take the highest office in the land. Trump may soon discover that railing against political correctness is easier to do as a candidate than as president of the entire nation. Whatever he does with that discovery will exact political costs.

Second, just as Obama discovered that norms about presidential discourse serve a purpose, Trump will as well. You cannot call people stupid when you have access to the nuclear codes; it's not an interaction between equals once you have taken office. Not all American citizens will find Trump's language distasteful - the election showed that. But the tides may shift when he takes office.

Obama's rhetoric as a candidate also succeeded because he offered a positive vision of the US alongside his critiques of the Bush administration. The speech that launched his career as a national

"Not all American
citizens will find
Trump's language
distasteful - the
election showed
that. But the tides
may shift when he
takes office."

"Not all American citizenswill find Trump's language distasteful - the election showed that. But the tides takes office." 
politician, at the 2004 Democratic national committee, envisioned not a red-and-blue America, but a United States of America, where lives were complicated and values were shared. Trump's America, as described in his speeches, is a bleak and violent one. He talks about restoring past greatness, a message that is clear enough to his listeners even without the more explicit racial rhetoric. Obama's state of the union address in January 2015 revealed how strained his original vision has been, including passages like 'we may have different takes on events in Ferguson and New York. But surely we can understand a father who fears his son can't walk home without being harassed. Surely we can understand the wife who won't rest until the police officer she married walks through the front door at the end of his shift.' For a presidential candidate from the opposition party it's relatively straightforward to offer compelling criticism. Articulating a positive vision is more challenging.

Furthermore, when Trump is not inciting anger, he is talking about infrastructure and other basic matters of governance. If rhetoric is, in fact, the glue that holds his party together, governance will soon prove a different and more formidable challenge. Republicans enjoy congressional majorities but major fissures in the party remain. Bringing the house freedom caucus on board with an infrastructure agenda may prove difficult, for example. American political parties are much more powerful as abstract ideas that shape loyalties than as organisations that shape governance decisions. Rhetoric is a key vector of those ideas. But this leaves presidents with little leverage at key moments.

US presidential politics is defined by a dynamic legacy of how presidents define and justify their power and make themselves seem at turns ordinary and dignified, intimately tied to the people and removed from them. The presidency also features pendulum swings between parties and visions for the nation. Obama's main legacy for his successor may be that a robust vision takes more than rhetoric to sustain.

\section{AND NOW... PRESIDENT TRUMP}

\section{Timothy Shenk is a Mellon postdoctoral fellow at Washington University in St Louis, Carnegie fellow at the New America thinktank, and book editor at Dissent magazine.}

Donald Trump is not really a businessman. He is more like television's version of a businessman. Although he depicts himself as a captain of industry, his greatest skill is brand management. That's why he was the perfect choice to decide actor Gary Busey's fate on The Celebrity Apprentice. Trump's knack for self-promotion served him well in the presidential campaign. It will prove less useful in the White House, where managing the ungainly apparatus of the 
executive branch and stitching together majorities on Capitol Hill take priority. Nobody can predict how Trump will respond to these challenges. But historical experience and his own words suggest that his administration is likely to proceed along one of three routes.

He could try to be like Ronald Reagan. This would be the easiest path for Trump to follow because it is the one for which congressional Republicans have been clearing the way since 2009. With the White House and congress in their hands, Republicans are ready to push through an agenda that rivals the New Deal in its scope. Repealing Obamacare and privatising Medicare (the federal programme that provides non-means-tested health coverage for people aged 65 and over or have a severe disability), tax cuts whose benefits would flow overwhelmingly to the rich, massive reductions in non-defence discretionary spending and sweeping deregulation are all on the agenda. Twenty-first century Reaganism would add some new twists - torpedoing the Paris climate agreement, for example - but the contours of this programme would be recognisable to the Gipper.

Or he could try to be like Richard Nixon. Although Nixon today is remembered for the abuses of power that forced his resignation, two years before he left office he won reelection by one of the largest margins in American history. He owed his success to his ability to coopt popular Democratic policies while representing himself as the champion of a silent majority that had been overshadowed by unruly forces on the streets and in the universities. Twenty years later, Nixon's former aide Pat Buchanan resurrected his old boss's rightwing populism in his own run for the White House; today, Buchanan proudly describes Trump as his heir. This is the Trump who called his campaign an opportunity to 'declare independence from the elites who've led us to one financial and foreign policy disaster after another'. An administration guided by this strategy would be willing - even eager - to flout Republican orthodoxy. Trump's chief strategist Steve Bannon has already predicted the fallout. 'The conservatives are going to go crazy,' he told an interviewer shortly after the election. 'It will be as exciting as the 1930s, greater than the Reagan revolution conservatives, plus populists, in an economic nationalist movement.'

Or he could try, simply, to be like Donald Trump. During the campaign, Trump mixed authoritarian impulses with an emphasis on the need for independent citizen-politicians, a blend that vaguely recalls Andrew Jackson but has had no recent precedents in the White House. This is the Donald Trump who has called for a temporary ban on Muslims entering the United States, supports ending birthright citizenship, sows doubt about the reliability of elections when he thinks he's going to lose, admires Vladimir Putin's 'strong' leadership, wants a deportation force targeting millions of undocumented immigrants, incites violence against protesters at his rallies, endorses changing libel laws to make it easier to seek retribution for unfavourable coverage, and threatens to jail his opponents. But this is also the Donald Trump who listed term limits as the lead item in

\section{“Trump's knack for self-promotion served him well in the presidential campaign. It will prove less useful in the White House."}


the plan for his first 100 days in office, vowed to 'drain the swamp' in Washington, and knows that telling his supporters he can never be bought is one of his best applause lines.

In practice, Trump is likely to combine all three approaches, just as Nixon and Reagan did before him. Both Nixon and Reagan had their own forays with executive overreach - Watergate brought down Nixon, Iran-Contra could have done the same for Reagan - and both knew when to act the part of ideologue and when to cut a deal. The balance Trump strikes among these strategies will determine the major battles of the years ahead. Candidate Trump, for example, followed the Nixon path and pledged to leave Medicare and social security untouched. Nobody knows what he will do when Paul Ryan pushes him to revisit those subjects from a more Reaganesque perspective. Congressional Republicans might check Trump's authoritarian and populist instincts - or they might hide in their offices and play dead. After a year that has defied every political convention, anyone who claims to know for sure what happens next is lying.

Cutting across all of this is the more basic issue of competence. According to the New York Times, in the spring of 2015 Donald Trump Jr offered Ohio governor John Kasich the vice-presidential nomination on behalf of his father, promising that Kasich 'would be in charge of domestic and foreign policy' while the president occupied himself with 'making America great again'. Even if Trump wants to use the presidency to do more than funnel clients to the Trump Organisation, it is not clear if he will be competent enough to do the job. That will become especially important when - and it's a matter of when not if - he's confronted with an emergency that forces him to make decisions that will have global ramifications.

Americans have elected a man who made a career out of playing television's version of a businessman. Now we're going to discover whether he just wants to be television's version of a president.

\section{"Congressional Republicans might check Trump's authoritarian and populist instincts - or they might hide in their offices and play dead."}

